Vol. 5 (1996): 311-327.

\title{
Impact of global warming on potato late blight: risk, yield loss and control
}

\author{
Timo Kaukoranta \\ Agricultural Research Centre of Finland, Institute of Plant Protection, FIN-31600 Jokioinen, Finland
}

\begin{abstract}
The impact of climate warming on yield losses caused by potato late blight and on the need for disease control was studied by constructing models for timing late blight epidemics and a model of potato growth constrained by late blight. Empirical models predicting the date of planting and emergence of potato were based on thermal time, and a model predicting the date of late blight outbreak was based on thermal time on rainy days. Experiments were conducted over 3 years under ambient and elevated $\left(+3^{\circ} \mathrm{C}\right)$ temperatures to obtain parameter values for the growth model. Potato emergence is predicted to occur at 631 degree days accumulated above $0^{\circ} \mathrm{C}$ after the 16 -day running mean temperature in spring exceeds $0^{\circ} \mathrm{C}$. A blight outbreak is predicted to occur when the effective temperature sum accumulated above $8^{\circ} \mathrm{C}$ after potato emergence, on days with at least $0.1 \mathrm{~mm}$ of precipitation, achieves 156 degree days. In the prediction of the outbreak the maximum daily accumulation of temperature is limited to 10 degree days. A preliminary sensitivity study carried out at one site in southern Finland suggests that over a range of 1 to $3^{\circ} \mathrm{C}$ warming, the period during which late blight needs to be controlled by fungicide applications would be $10-20$ days longer per $1{ }^{\circ} \mathrm{C}$ of warming. The increase in yield loss of unprotected crops would be of the same magnitude as the increase in yield potential, around $2 \mathrm{t} /$ ha of dry matter per $1^{\circ} \mathrm{C}$ of warming.
\end{abstract}

Key words: Phytophthora infestans, climatic change, risk evaluation, model

\section{Introduction}

Predicted future climate warming and the rise in carbon dioxide concentrations (IPCC 1990) are generally believed to affect the risks of pest and disease damage to agricultural crops (e.g. Coakley 1988, Harrington and Stork 1995). In northern latitudes, the risks would be expected to increase with warming, because low temperatures and the long winter currently reduce the survival, number of generations per year, reproduction rate and activity of most of the pests and pathogens attacking crops during the growing season.

The economic importance of potato late blight (Phytophthora infestans (Mont.) de Bary) might change significantly, as warming would 


\section{Kaukoranta, T.: Impact of global warming on potato late blight: risk, yield loss and control}

probably affect both the yield potential of potato and late blight epidemics. The yield potential is likely to increase with warming. Damage caused by the pathogen might also increase, if warming allowed epidemics to start at least as early as they do in the current climate.

In this study, robust models have been developed to estimate the impact of global warming on yield losses caused by potato late blight and to time the planting and emergence of potato and the outbreak of the epidemic. These models were coupled to a simple crop growth model to estimate the reduction in green leaf area and tuber yield. A sensitivity test was conducted to study the effect of temperature changes on the date of blight outbreak, the need for fungicide use, and yield losses.

\section{Timing the epidemic}

\section{Definition of the problem and selection of methods}

Observations and models of the effect of weather on the reproduction of $P$. infestans and the progress of the epidemic abound (e.g. Crosier 1934, Beaumont 1947, Bourke 1955, Wallin 1962, Ullrich and Schrödter 1965, Smith and Seager 1974, Krause et al. 1975). Common to all the models considered successful in predicting the disease in a stable climate is a requirement for data on the duration of periods of high relative humidity (exceeding $75 \%$ or $90 \%$ ) and for temperatures during these periods. However, the duration of high relative humidity is not applicable in this study, because the models developed were to be applied nationally in Finland (cf. Carter et al. 1996), and daily data on relative humidity were not available over the whole country. Instead, the approach employs simple, empirical models. It is accepted that the models do not achieve the short-term accuracy of the best existing prediction models.
Regional late blight epidemics follow a roughly exponential growth curve. Initially the curve rises very slowly after the emergence of the potato, but after a sufficient accumulation of inoculum the curve turns sharply upwards for fields not protected against late blight. The turn is marked by the general appearance of the first symptoms, after which the haulm of susceptible varieties can be destroyed in 1 to 3 weeks. Regional and annual variations in the timing of symptom appearance are mainly governed by the weather, which determines the time of planting, the length of the emergence period and the rate of pathogen multiplication after potato emergence. Other factors affecting the variation are the amount of initial inoculum carried over from the previous season (Hirst and Stedman 1960, Croxall and Smith 1976) and the resistance of varieties.

For the purposes of this study the epidemic was divided into three phases: the period before symptom appearance, the period of rapid destruction of the haulm, and the period when all of the haulm is dead. The objective was to develop simple models for predicting the time of blight outbreak, which is here defined as the time of general appearance of first symptoms. As epidemics can only start after potato emergence, models for timing potato planting and emergence are also needed.

The date of planting and of emergence of potato is predicted by models based on thermal time, and the date of blight outbreak by a model based on thermal time and precipitation. Base temperatures and the thresholds of the effective temperature sum were estimated by minimizing the sum of squared deviations of the observed dates from those predicted. A Pascal computer program was used to search for parameter values by iterating through all possible values at steps of $1^{\circ} \mathrm{C}$ or 1 degree day. Daily weather data used for estimating the parameters of the models were obtained from the Finnish Meteorological Institute (FMI) and extracted from the database managed by the Agricultural Research Centre (Maatalouden tutkimuskeskus 1989). 
Vol. 5 (1996): 311-327.

\section{Models for predicting planting and emergence of potato}

The time of planting for maincrop varieties was assumed to depend on the effective temperature sum accumulated in spring (from 1 March) after the 16-day running mean temperature exceeded a certain base temperature. Sixteen days was found to be the optimum period for smoothing the spring temperatures, to avoid the possibility of a brief, early warm spell unrealistically advancing the estimated planting date (T. Carter, pers. comm., 1995). Planting dates of 145 variety trials with 758 observations on emergence (several varieties) carried out by the Potato Research Institute, Lammi, Finland, during 19831994 (Perunantutkimuslaitoksen koetuloksia 1983-1994) and in 1977, 1979 and 1980 by Hämeen Peruna Oy (Perunakoetuloksia 1977, 1979,1980 ) were used to find base temperatures, between $0^{\circ} \mathrm{C}$ and $5^{\circ} \mathrm{C}$, and threshold temperature sums. The experimental sites are shown in Fig. 1.

With the minimization procedure it was estimated that planting takes place after 337 degree days have accumulated above $0^{\circ} \mathrm{C}$ (DD0). Development from planting to emergence was found to require $294 \mathrm{DD} 0$. Both models explain $48 \%$ of the variation in data. As both models had the same base temperature, they were combined to give a model which predicts potato emergence 631 DD0 after the 16 day mean temperature exceeds $0^{\circ} \mathrm{C}$ in the spring. Model predictions are compared with observations in Figs $2 \mathrm{a}$ and $2 \mathrm{~b}$.

\section{A model for timing the outbreak of the epidemic}

The date of outbreak of late blight (Day sym $_{\text {s }}$ was predicted on the basis of temperatures accumulated over wet days after potato haulm emergence. To reduce the potential error caused by the high spatial variation in daily precipitation, the precipitation was transformed to a discrete scale with two possible values: $<0.1 \mathrm{~mm}$ and

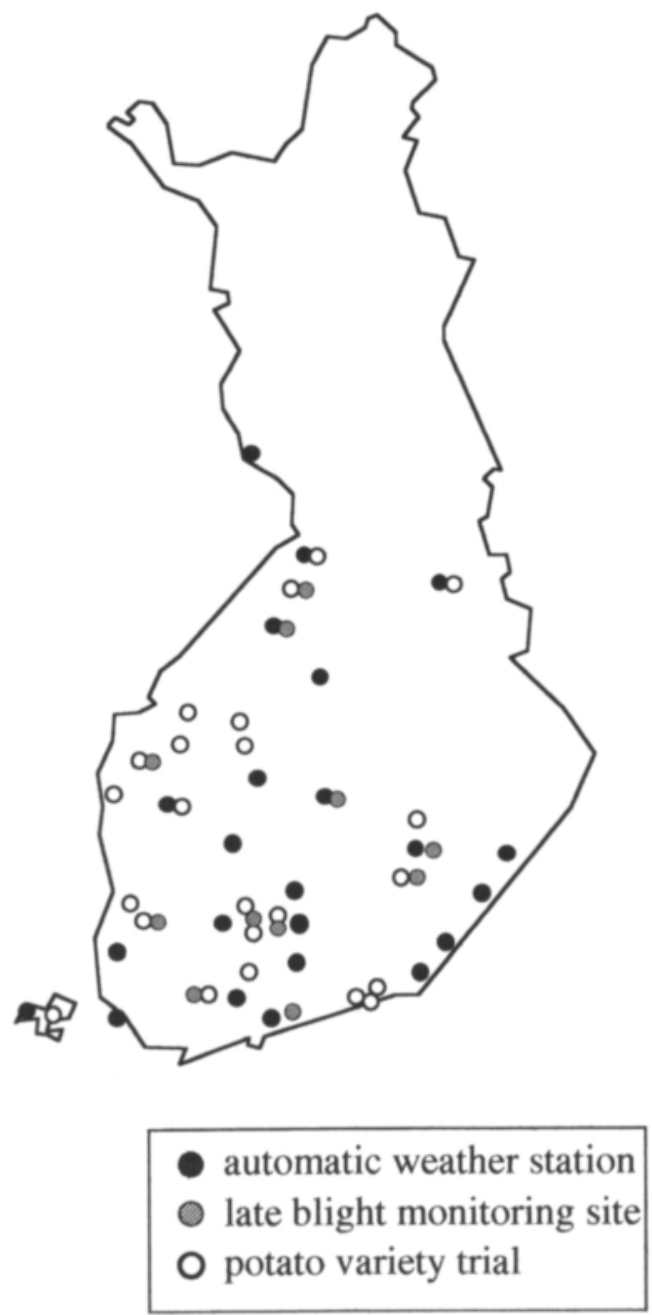

Fig. 1. Locations of potato variety trials in 1977-1994, automatic weather stations in 1993-1994 and late blight monitoring sites in 1975-1994.

$\geq 0.1 \mathrm{~mm}$. On days with at least $0.1 \mathrm{~mm}$ of precipitation $\left(p_{i} \geq 0.1\right)$ the rate of multiplication of the disease is governed by the daily average temperature $\left(\mathrm{T}_{i}\right)$. Its effect on the rate is described by an effective temperature sum model with a base temperature $T_{b}$ and an upper limit for daily 
Kaukoranta, T.: Impact of global warming on potato late blight: risk, yield loss and control
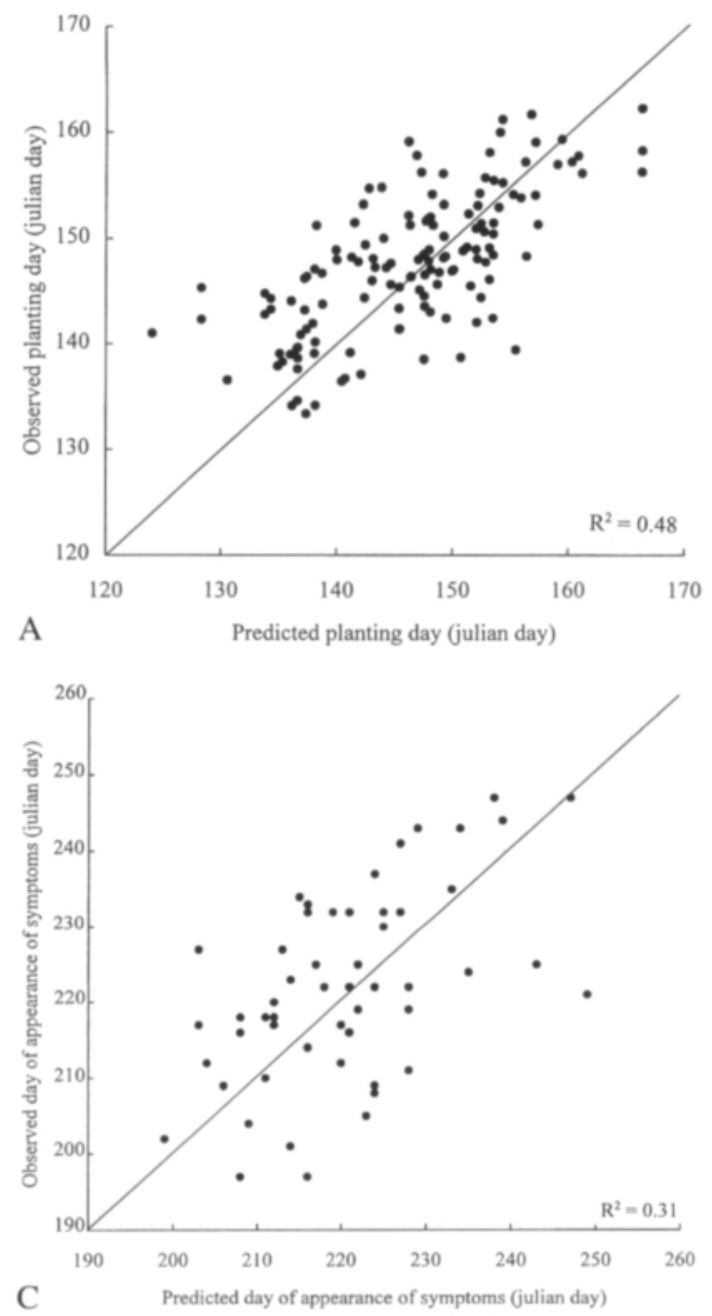

effective temperature $T_{\max }$. The outbreak is predicted to occur on the day $\left(\right.$ Day $\left._{\text {sym }}\right)$ when the accumulated temperature on rainy days (ETS) exceeds a threshold requirement $\left(\right.$ ETS $\left._{\text {sym }}\right)$ :

$$
\begin{aligned}
& \mathrm{ETS}=\sum_{\mathrm{i}} \operatorname{MAX}\left\{0,\left(\operatorname{MIN}\left\{\mathrm{T}_{\mathrm{i}}, \mathrm{T}_{\max }\right\}-\mathrm{T}_{\mathrm{b}}\right)\right\}, \\
& \mathrm{i}=1 . . \text { Day }_{\text {sym }}, \mathrm{p}_{\mathrm{i}} \geq 0.1
\end{aligned}
$$

The negative prediction model of Ullrich and Schrödter (1965), developed in Germany and recently validated in the Nordic countries

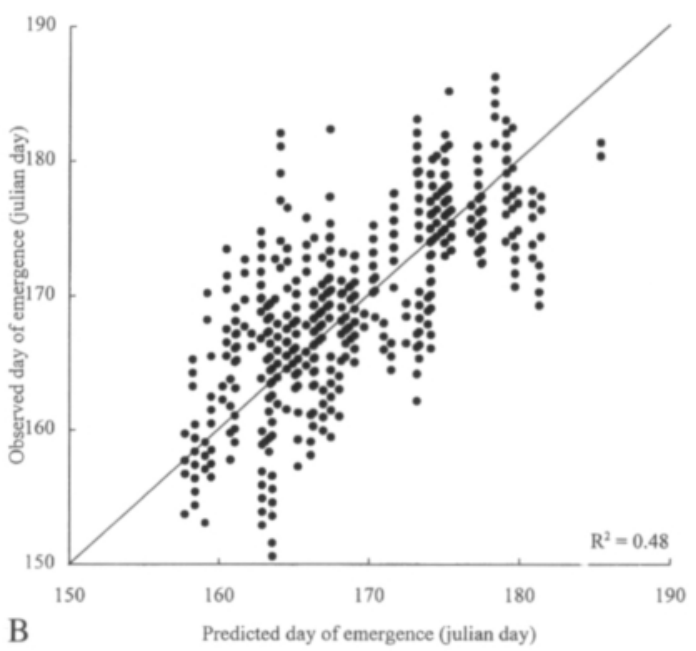

Fig 2. Comparison of the predicted and observed days of (a) planting, (b) emergence and (c) appearance of the first late blight symptoms. 13 points superimposed in $2 \mathrm{a}$ and 371 points in $2 b$.

(Hansen and Holm 1991, Hansen et al. 1995), was used for setting the initial values of the parameters $T_{b}, T_{\max }$, ETS $_{\text {sym }}$. The program code of the model was provided by E. Friis and J. Hansen of the Foulum Research Centre, Denmark. Control structures of the program were modified to suit the needs of this work but, in essence, the negative prediction model was kept in its original form.

The initial values of the base temperature $\left(T_{b}\right)$ and maximum effective temperature $\left(\mathrm{T}_{\max }\right)$ were estimated by running the negative prediction model with 3-hourly data on temperature and relative humidity $(\mathrm{RH})$ recorded by automatic weather stations in 1993-1994 at sites shown in Fig. 1 (Ilmatieteen laitos 1995). The model runs indicated that if the daily average temperature was below $7^{\circ} \mathrm{C}$ on a rainy day, the daily output value of the negative prediction model was generally around zero, indicating that late blight does not multiply on those days. As the temperature rose from $7^{\circ} \mathrm{C}$ to $15-21^{\circ} \mathrm{C}$, the output value increased. 
Vol. 5 (1996): 311-327.

The final values of $\mathrm{T}_{\mathrm{b}}, \mathrm{T}_{\max }$ and ETS $\mathrm{sym}_{\text {mere }}$ determined using the minimization procedure with data on the appearance of first late blight symptoms, daily mean temperature and daily precipitation. The function to be minimized was the sum of squared deviations of the observed dates of symptom appearance from the dates of outbreak predicted by the model.

The data on symptom appearance consisted of 55 observations on unsprayed plots of cv. Bintje. Twenty-six observations were derived from the results of mainly unpublished field experiments conducted during 1974-1991 in plots measuring $2 \times 10 \mathrm{~m}$. Twenty-nine observations were made during 1992-1994 in unsprayed plots measuring $10 \times 10 \mathrm{~m}$, where the emphasis was on accurate observation of the appearance date of first symptoms. The field experiments and observations were conducted by the Institute of Plant Protection and research stations of the Agricultural Research Centre (Satakunta, South Ostrobothnia), the Institute of Potato Research, Lammi, and Päijät-Häme Agricultural Institute, Asikkala. The observation sites are shown in Fig. 1. As the observations were made by several people and during 1974-1991, not specifically intended to record an accurate date of symptom appearance, the symptoms were probably not always reported immediately after they appeared.

The outbreak of late blight was estimated to require 156 degree days accumulated above $8^{\circ} \mathrm{C}$ $\left(\mathrm{T}_{\mathrm{b}}\right)$ on days with at least $0.1 \mathrm{~mm}$ of precipitation after potato emergence (DD8). The maximum daily effective temperature $\left(\mathrm{T}_{\max }\right)$ was limited to $18^{\circ} \mathrm{C}$.

The models predicting the emergence day and the outbreak were run for 55 combinations of year and site using the daily average temperature and precipitation measured at these sites. The predicted dates of the disease outbreak are compared with the observed dates in Fig. 2c. The combined models could discriminate between early and late outbreaks, but a large part of variation in the date of disease outbreak remained unexplained, as the coefficient of determination was 0.31 .

\section{Effect of late blight on potato growth}

\section{Selection of methods}

Rotem et al. (1983), Haverkort and Bicamumpaka (1986) and Oijen (1991) have shown that the effect of late blight on potato growth can be largely explained by the reduction in green leaf area over a growing season. The radiation use efficiency (RUE) of green foliage was found to be insensitive to the disease. A simple model, such as those published by MacKerron and Waister (1985) and Jefferies and Heilbronn (1991), which describe leaf area expansion by thermal time, calculate radiation interception as a function of green leaf area and transform the intercepted radiation to dry matter by RUE, should thus be sufficient to estimate tuber dry matter accumulation in both healthy and infested crops.

\section{Model structure}

In the growth model adopted for this study, the interception of photosynthetically active radiation (PAR) by the plant canopy after haulm emergence is computed from the leaf area index (LAI) and daily total radiation using an exponential light extinction curve. The form of the curve is determined by an extinction coefficient $(\mathrm{k})$. The intercepted PAR is converted into daily production of dry matter by a constant RUE. Part of the dry matter production is allocated to tubers (DM) according to an allocation parameter (A). LAI and $\mathrm{A}$ are given as a function of accumulated temperature above $5^{\circ} \mathrm{C}$ after emergence. $\mathrm{LAI}$ is assumed to remain constant until harvest, since under the conditions prevailing during a short growing period, long days and ample nitrogen fertilization, LAI does not generally decrease very much before the haulm is removed prior to harvesting. The daily growth of tubers is given by equation 2

(2) $\mathrm{DM}=(1-\exp (-\mathrm{k} * \mathrm{LAI})) * \mathrm{PAR} * \mathrm{RUE} * \mathrm{~A}$

Late blight affects growth by reducing LAI 


\section{AGRICULTURAL AND FOOD SCIENCE IN FINLAND}

Kaukoranta, T.: Impact of global warming on potato late blight: risk, yield loss and control

linearly from its normal value to zero in 14 days after the predicted outbreak of epidemic.

\section{Experiments and parameter estimation}

The values of LAI, RUE and A were estimated from field experiments conducted at ambient and elevated temperatures at Jokioinen in 19931995. Ambient temperature was measured at a height of $2 \mathrm{~m}$ and elevated temperature conditions were created by regulating the temperature at $2 \mathrm{~m}$ height in a large greenhouse to follow the ambient temperature at a level $3^{\circ} \mathrm{C}$ above it. Temperatures under the ambient and elevated temperature conditions were not essentially different in the early stages of crop development, as the potato was planted 3 to 4 weeks earlier under elevated than under ambient temperature conditions. The experimental site, equipment and weather conditions are reported in Hakala et al. (1996).

Two varieties were used in all experiments: cv. Bintje (Netherlands) and cv. Pito (Finland). The varieties differ in earliness under current climatic conditions, cv. Bintje being a relatively early and cv. Pito a late type, with respective differences in the course of LAI and tuber filling rate over the growing season. Both varieties are fairly susceptible to late blight, though $\mathrm{cv}$. Bintje is clearly more susceptible than cv. Pito.

High grade seed for the experiments, averaging $30 \mathrm{~mm}$ in diameter, was produced by the Seed Potato Centre at Tyrnävä. Before planting the tubers were pre-sprouted for 2 weeks at 5$10^{\circ} \mathrm{C}$. Five rows of both cultivars, each $8 \mathrm{~m}$ long and spaced $0.7 \mathrm{~m}$ apart, were planted in ambient and elevated temperature conditions. The distance between plants was $0.33 \mathrm{~m}$. The crops were fertilized with NPK fertilizer at a rate of $80 \mathrm{~kg} /$ ha nitrogen and irrigated by drip irrigation lines along the top of ridges and by misting from above the crop. The mist was produced by passing water through nozzles at approximately $2 \mathrm{l} / \mathrm{min}$ at an applied pressure of $500 \mathrm{kPa}$. The nozzles were assembled $1.5 \mathrm{~m}$ apart in parallel pipelines at a height of $1.5 \mathrm{~m}$.

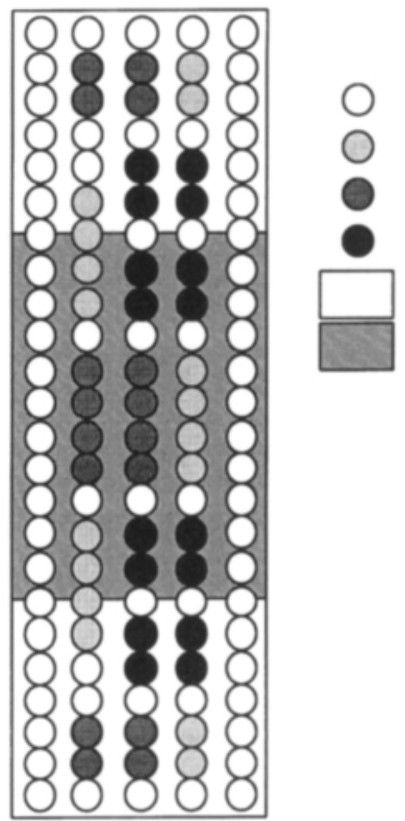

not harvested

harvest 1

harvest 2

harvest 3

healthy plants

inoculated plants

Fig. 3. Set up of plots for one cultivar and one temperature condition. Plants shown with circles. Harvest times indicated in grey tone. Two adjacent plants in a row with the same tone form a harvesting plot. Background shading shows the healthy and inoculated areas.

Half of the row length was inoculated with $P$. infestans on dates considered representative of the start of late blight at ambient and elevated

Table 1. Dates of planting, inoculation and harvesting of the experiments in ambient and elevated $\left(+3^{\circ} \mathrm{C}\right)$ temperatures at Jokioinen in 1993-1995.

\begin{tabular}{|c|c|c|c|}
\hline & 1993 & $\begin{array}{c}\text { Year } \\
1994\end{array}$ & 1995 \\
\hline \multicolumn{4}{|c|}{ Ambient temperature } \\
\hline Planting & 1 Jun & 23 May & 29 May \\
\hline Inoculation & $29 \mathrm{Jul}$ & 2 Aug & - \\
\hline Harvest 1 & $29 \mathrm{Jul}$ & 2 Aug & 24 Jun \\
\hline Harvest 2 & 17 Aug & 23 Aug & 10 Aug \\
\hline Harvest 3 & 8 Sep & 7 Sep & 20 Sep \\
\hline \multicolumn{4}{|c|}{ Elevated temperature } \\
\hline Planting & 10 May & $25 \mathrm{Apr}$ & 2 May \\
\hline Inoculation & $8 \mathrm{Jul}$ & 22 Jun & 30 Jun \\
\hline Harvest 1 & $8 \mathrm{Jul}$ & 22 Jun & 30 Jun \\
\hline Harvest 2 & 4 Aug & $18 \mathrm{Jul}$ & $20 \mathrm{Jul}$ \\
\hline Harvest 3 & 8 Sep & 25 Aug, 7 Sep & 4 Sep \\
\hline
\end{tabular}




\section{AGRICULTURAL AND FOOD SCIENCE IN FINLAND}

Vol. 5 (1996): 311-327.

1993

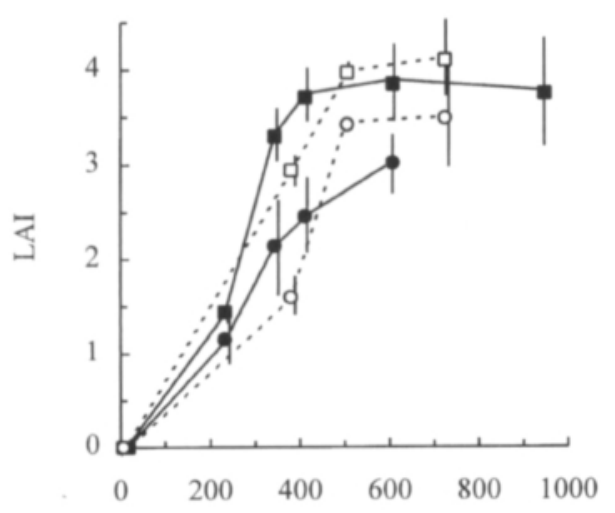

Accumulated temperature (DD5)

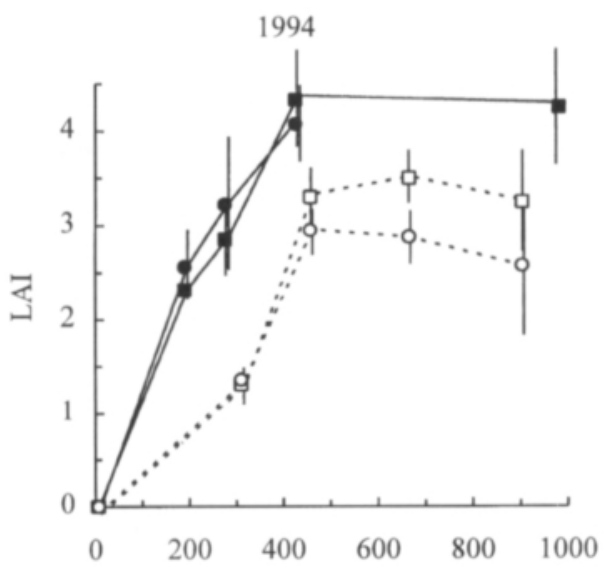

Accumulated temperature (DD5)

1995

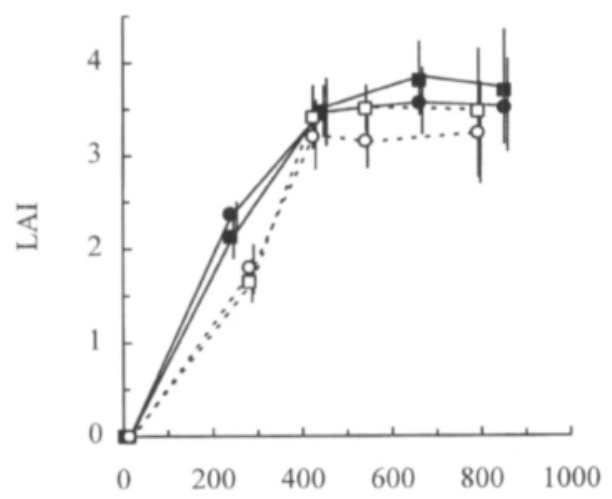

- o - cv. Pito ambient temp.

- - cv. Pito elevated temp.

- o - cv. Bintje ambient temp.

$\rightarrow-c v$. Bintje elevated temp.

Accumulated temperature (DD5)

Fig. 4. LAI of healthy crops as a function of degree days after emergence, base temperature $5^{\circ} \mathrm{C}$, at ambient and elevated $\left(+3^{\circ} \mathrm{C}\right)$ temperatures in 1993-1995. Bars indicate standard errors of the mean with $95 \%$ probability.

temperatures (Fig. 3). The other half was kept free of late blight by applying Ridomil MZ (metalaxyl + mancozeb) or Tattoo (propamocarb HCL + mancozeb) at intervals of 1 to 2 weeks. Crops under ambient temperatures were not inoculated in 1995. The canopies were thoroughly wetted by misting in the evening, then a homogenized mixture of mycelium, spores and water was sprayed onto the leaves with a bottle-sprayer. From 10 to 20 leaves were kept covered with plastic bags for the next 12 hours to ensure that at least some leaves would be infected. For the next 2 days the crops were misted between 0900 and 2000 hours every 15 minutes for 10 seconds at a time. The misting was continued during most nights from 2000 to 2400 hours until the death of the inoculated foliage. The dates of planting and inoculation are given in Table 1.

Inoculation of leaves with $P$. infestans succeeded well. Symptoms appeared 3 to 4 days 
Kaukoranta, T.: Impact of global warming on potato late blight: risk, yield loss and control
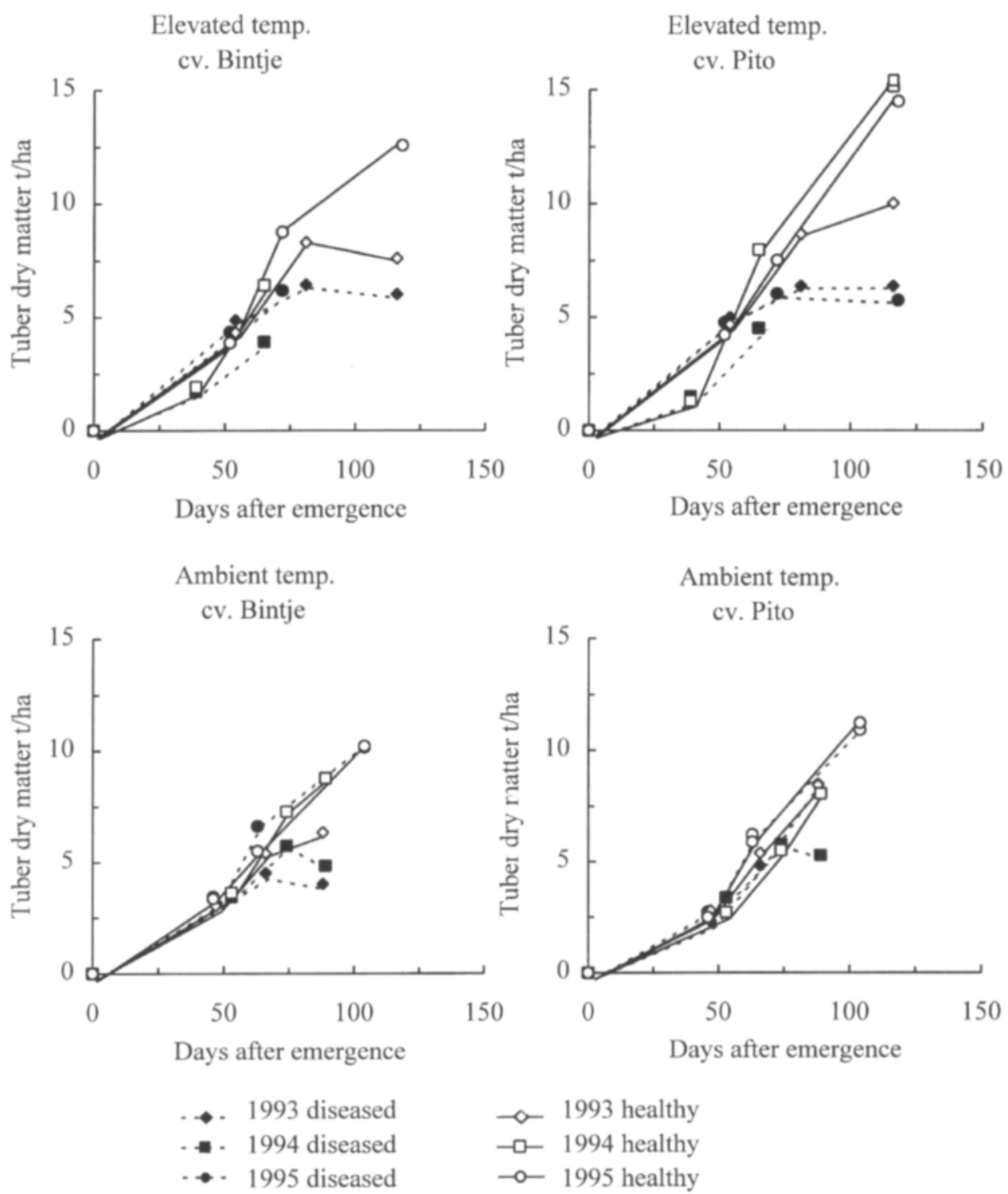

Fig. 5. Tuber dry matter accumulation in healthy and diseased crops following emergence at ambient and elevated $\left(+3^{\circ} \mathrm{C}\right)$ temperatures in $1993-1995$.

after the inoculation, both on the leaves kept in plastic bags and on those kept wet by misting. The misting provided conditions under which disease lesions grew fast and blight spread to all plants not protected by fungicide.

To determine the dates when new tubers started growing, stolon ends were occasionally ex- posed at two to five places for both cultivars and temperatures. The day on which the tips of stolons were clearly expanded was marked as the day of tuber initiation. Dry matter accumulation in healthy and diseased crops was measured by harvesting four plots three times a season in both healthy and inoculated areas. The layout of the 
Vol. 5 (1996): 311-327.
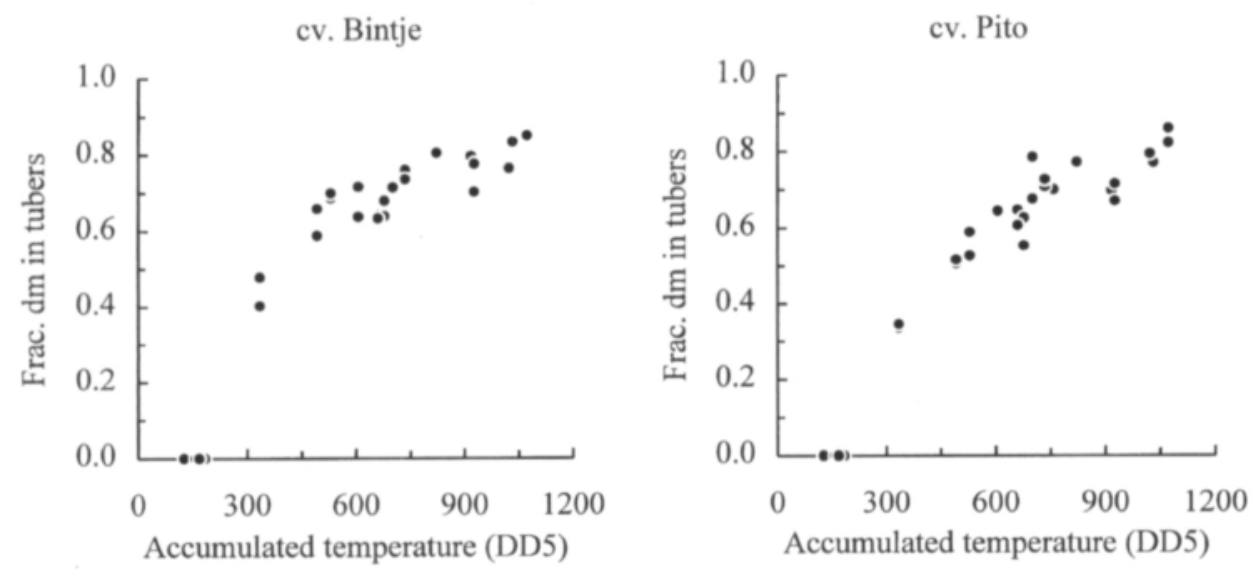

Fig. 6. Fraction of total dry matter found in tubers as a function of degree-days after emergence, base temperature $+5^{\circ} \mathrm{C}$. Pooled data over 1993-1995 and at both temperature levels.

harvesting plots is given in Fig. 3. Each plot consisted of two plants in a row, separated by a guard from surrounding plots in the same row which were harvested at different times. The plants were separated into tubers, roots, stems and leaves, cut into small pieces, dried at $60^{\circ} \mathrm{C}$ for 24-48 hours in paper bags and weighed. The dates of harvesting are given in Table 1 .

LAI in the healthy area was measured with a portable plant canopy analyzer (type LAI-2000, LI-COR Inc., USA). Good estimates of LAI were not obtained after the second harvest, which was indicated by the high variability in the belowcanopy readings of the plant canopy analyzer. The variability was caused by holes in the canopy created by harvesting and by lodging in the plots of cv. Bintje under elevated temperatures in 1994. Four to eight separate estimates of LAI, each of them means of eight below-canopy measurements, were taken for each cultivar and temperature level. The estimates taken at one time were averaged to get a single value of LAI for each cultivar and temperature level.

The course of LAI as a function of accumulated temperature above $5^{\circ} \mathrm{C}$ (DD5) after emergence during the three seasons 1993-1995 is shown in Fig. 4 for cvs. Bintje and Pito. The highest values of LAI, attained between 400 and 500 DD5, were approximately 2.5 to 4 for cv.
Bintje and 3.5 to 4 for cv. Pito, respectively. Once the maximum was reached, LAI remained relatively constant until at least 800 to 900 DD5. In 1994, the LAI of both cultivars remained clearly lower at ambient than at elevated temperatures throughout the season.

Tuber dry matter accumulation is given in Fig. 5 as a function of days after emergence. In Fig. 6, the fraction of total plant dry matter stored in tubers is given as a function of accumulated temperature after emergence (DD5). Values are based on the harvest measurements on the healthy crops pooled over 1993-1995 at both temperature levels. Each value plotted in the figure is a mean of four harvesting plots. The zero values of the fraction show when the first stolon ends were found expanded. The tubers of both varieties are seen to start growing at practically the same time, on average after 160 DD5.

The harvesting intervals were too long and harvests were sometimes too late to allow the accurate determination of the date after which all new dry matter went to tubers. From the calculated ratios of the rise in tuber dry weight to the rise in total dry weight over a harvesting interval and the LAI observations, it was deduced that all assimilates were allocated to tubers approximately after 450 DD5 in cv. Bintje and after 550 DD5 in cv. Pito. 
Kaukoranta, T.: Impact of global warming on potato late blight: risk, yield loss and control
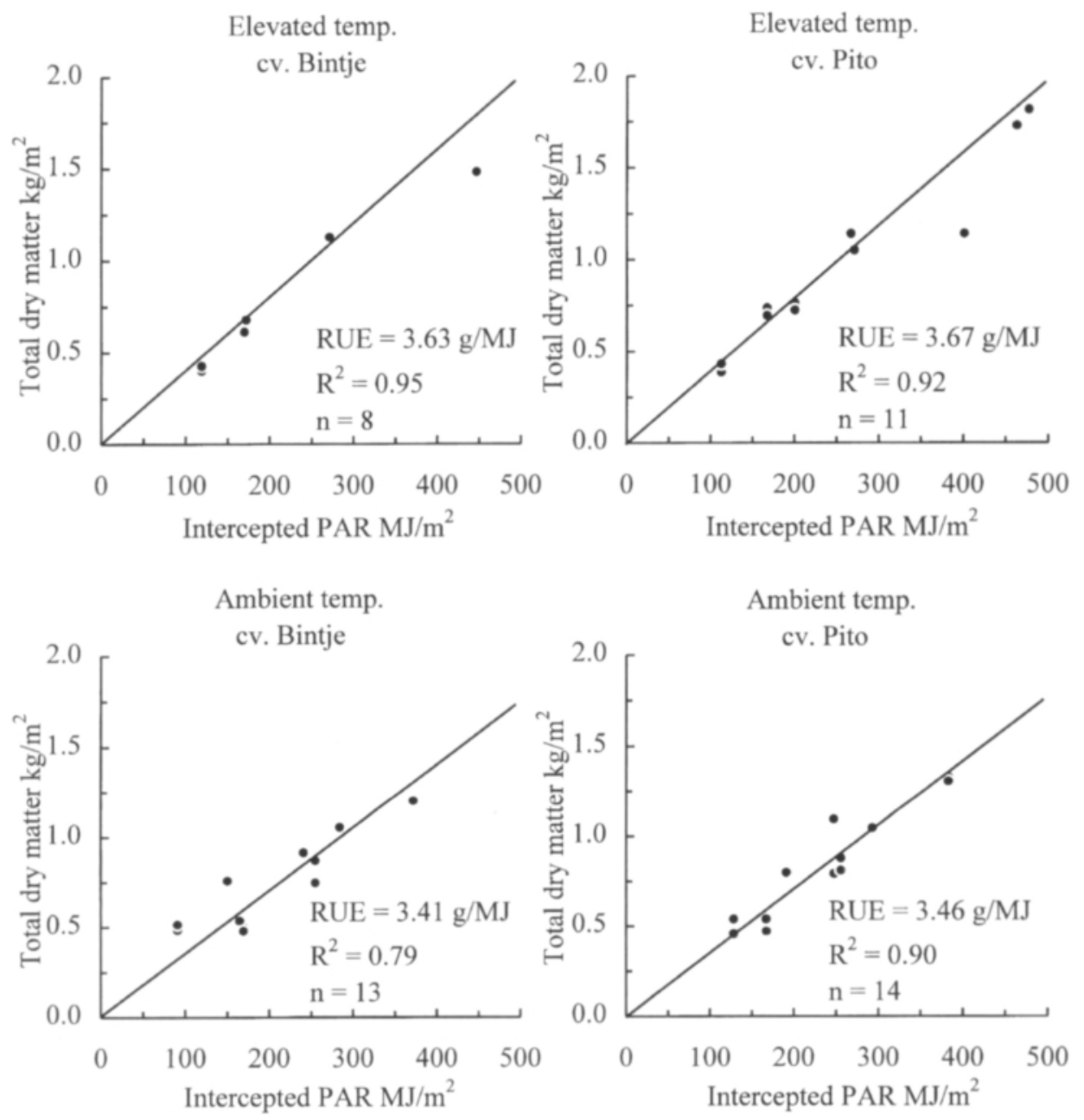

Fig. 7. Relation of the observed total dry matter accumulation and estimated intercepted PAR at ambient and elevated temperatures in 1993-1995. Radiation use efficiency (RUE) is the slope of the least squares regression line (also shown).

RUE of healthy crops was estimated by dividing the dry matter accumulated over a harvesting interval by the intercepted PAR. The intercepted PAR was calculated from the observed LAI and an extinction coefficient $(\mathrm{k})$ of 0.55 , as reported by Firman and Allen (1989). A single value of $\mathrm{k}$ was used, as the growth model employed is not sensitive to small changes in the extinction coefficient. PAR was derived from the total daily radiation (FMI, Jokioinen) by assuming that the proportion of PAR in the total radia- tion is 0.5 (Monteith and Unsworth 1990). The reduction in PAR due to the plastic film above the experiments was taken into account by multiplying PAR by 0.6 (Hakala et al. 1996).

The total dry matter accumulated over a harvesting interval is plotted against the calculated intercepted radiation in Fig. 7. A very clear linear relationship is observed between the intercepted PAR and the dry matter accumulation. For each mega joule of intercepted PAR the crops produced between 3.41 and 3.67 grams of dry matter. 
Vol. 5 (1996): 311-327.

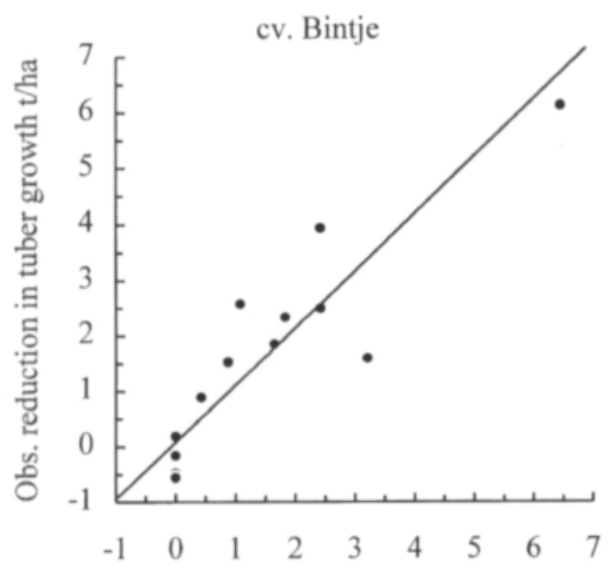

Pred. reduction in tuber growth $\mathrm{t} / \mathrm{ha}$

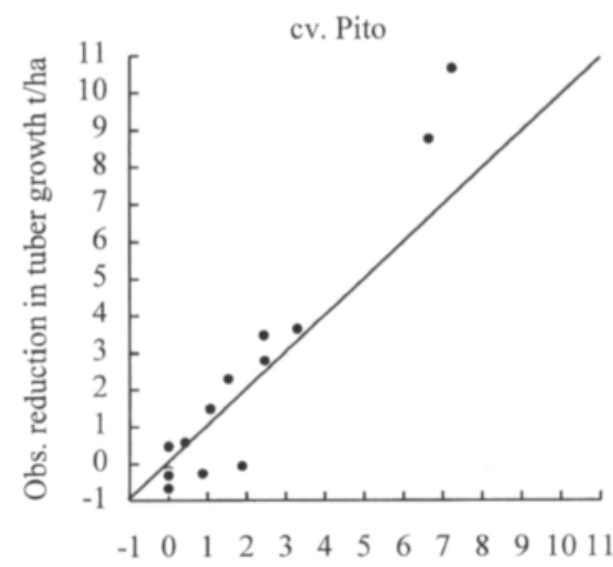

Pred. reduction in tuber growth tha

Fig. 8. Comparison of the predicted and observed reduction in tuber dry matter accumulation over a harvesting interval. Pooled data over 1993-1995 and at both temperature levels. Also shown is the predicted = observed line.

\section{Verification of the loss prediction method}

To test whether a model with a single set of parameters was robust enough to give yield losses reasonably similar to those observed, the growth model was run using the conditions measured in the experiments at ambient and elevated temperatures in 1993-1995. Because crops were not inoculated at ambient temperatures in 1995 and lodging probably reduced the growth of $\mathrm{cv}$. Bintje during the last harvesting interval in 1994, these observations were not included in computing growth reduction.

The value of the extinction coefficient (k) was set to 0.55 and RUE to 3.54. The proportion of dry matter allocated to tubers (A) and LAI were given as functions of daily mean temperature accumulated above $5^{\circ} \mathrm{C}$ (DD5) after emergence. The tuber allocation was 0 over the interval 0-160 DD5 and increased from 0 to 1 over the interval 160-450 DD5 (cv. Bintje), or 160550 DD5 (cv. Pito). LAI increased linearly from 0 to 3 over the interval 0-450 DD5 (cv. Bintje), or from 0 to 3.5 over the interval 0-550 DD5 (cv. Pito). The computations were started at the emergence dates observed in the experiments.
Late blight was set to start 5 days after inoculation and to reduce LAI linearly to zero in 14 days after the start.

Comparison of the predicted and observed reductions in tuber growth due to disease over a harvesting interval and over a season is shown in Figs 8 and 9, respectively. The total tuber loss over a season is not predicted very accurately, but the magnitude of the loss is correct.

\section{Sensitivity to temperature changes}

The sensitivity of the predicted time of disease outbreak and yield loss to temperature changes was studied with the models predicting the oubreak of the epidemic and the growth model for the 30 year period 1961-1990 at Jokioinen $\left(60^{\circ} 49^{\prime} \mathrm{N}, 23^{\circ} 30^{\prime} \mathrm{E}\right)$. Climatic data were obtained from FMI. The model was run for observed temperatures and for adjustments to these at intervals of $1{ }^{\circ} \mathrm{C}$ from -1 to $+3{ }^{\circ} \mathrm{C}$. Precipitation and radiation were kept unchanged.

An epidemic was predicted to start 631 DD0 


\section{AGRICULTURAL AND FOOD SCIENCE IN FINLAND}

Kaukoranta, T.: Impact of global warming on potato late blight: risk, yield loss and control

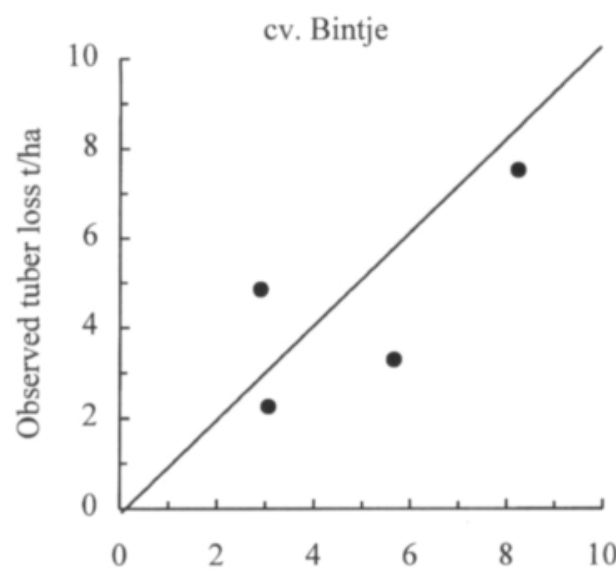

Predicted tuber loss t/ha

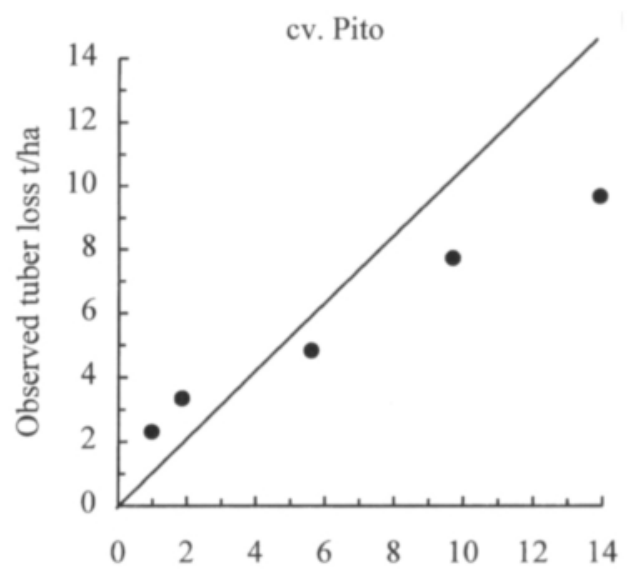

Predicted tuber loss tha

Fig. 9. Comparison of the predicted and observed reduction in tuber dry matter accumulation over a season. Pooled data over 1993-1995 and at both temperature levels. Also shown is the predicted $=$ observed line.

after the day on which the 16-day running mean temperature in spring exceeded $0^{\circ} \mathrm{C}$. Parameter values estimated for $\mathrm{cv}$. Pito (see above) were used in the growth model. LAI was kept at its maximum level until removal of the haulm, except when the growth of the infected crops was computed. In the latter case, LAI was reduced linearly to zero in 14 days after the predicted outbreak of the epidemic. Haulm removal of the healthy crop was assumed to take place 10 days before the day on which the 30 -year average daily temperature fell below $7^{\circ} \mathrm{C}$. This rule refers to the average date for the lifting of tubers at which growers aim by adjusting management practices (pers. comm. P. Kuisma). However, it ignores instances of premature haulm death due to frost or delayed harvest due to a late growing season.

The growth model was run twice for each temperature level, first by assuming that the late blight epidemic starts as predicted by the disease model and second, by assuming that the epidemic would start one week later than predicted. The purpose of the second run was to demonstrate the effect of possible errors in the date of blight outbreak on predicted yield losses.

The sensitivity test suggests that the period from potato emergence to haulm removal lengthens by 10 days, on average, per $1^{\circ} \mathrm{C}$ of warming if no factors other than temperature limit the length of the growing season. The accumulated temperature during this period would increase by about 170 DD5, on average, and the potential dry matter yield by about $2 \mathrm{t} /$ ha per degree of warming (Fig. 10a).

With each degree of warming the mean date of blight outbreak would shift earlier by 4-7 days. Since the mean date of haulm removal in a healthy crop is delayed by warming, these dates together determine the length of the period during which fungicide cover on potato needs to be maintained to prevent leaves from being infected, except during very dry spells. This period would lengthen by 10-20 days per degree of warming (Fig. 10b).

The simulated potential yield loss responds markedly to the change in temperature (Fig. 10c). On average, a $1{ }^{\circ} \mathrm{C}$ increase in temperature increased the yield loss of cv. Pito by $1.7 \mathrm{t} / \mathrm{ha}$ of dry matter, if epidemics started as predicted by the disease model. If epidemics started one week later than predicted, the average yield losses would be $0.5-1 \mathrm{t} / \mathrm{ha}$ less throughout the temperature range, but the impact of warming would still be the same. 


\section{AGRICULTURAL AND FOOD SCIENCE IN FINLAND}

Vol. 5 (1996): 311-327.

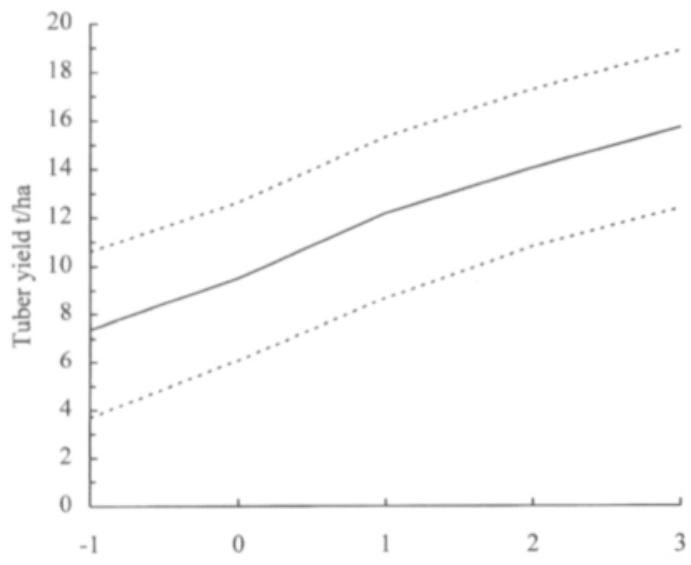

A

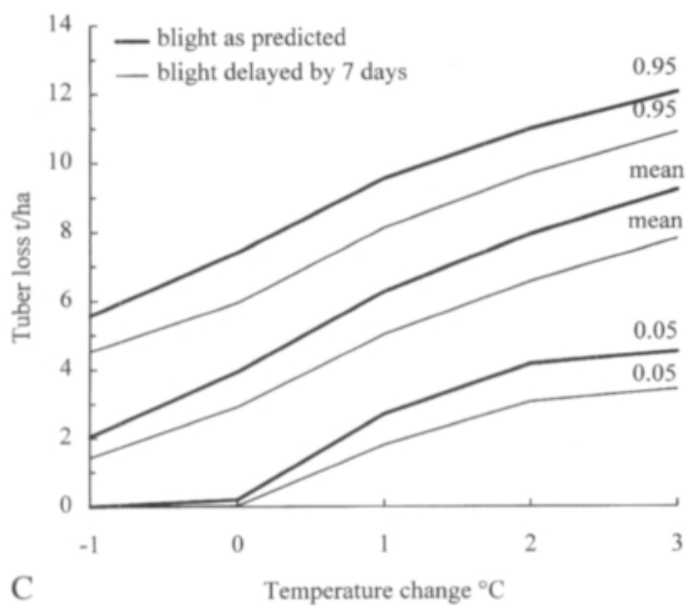

\section{Discussion}

The timing of potato emergence could be relatively well predicted by accumulating 631 DD0 from the day when the 16-day running mean temperature exceeds $0^{\circ} \mathrm{C}$. The data used for estimating accumulated temperature covers 18 years in the major potato-growing regions between latitudes $60^{\circ} \mathrm{N}$ and $65^{\circ} \mathrm{N}$ and longitudes $20^{\circ} \mathrm{E}$ and $28^{\circ} \mathrm{E}$. Its validity is limited to light, sandy soils, which warm rapidly after the melting of snow and frost. Only part of the variation in the

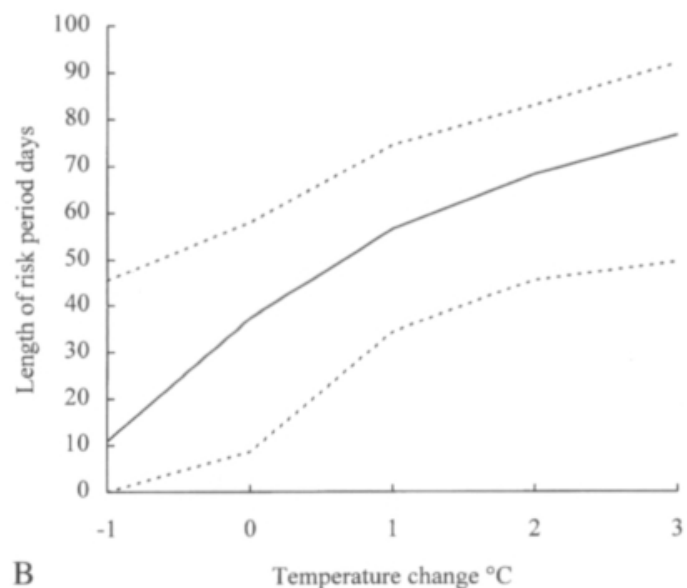

Fig. 10. Effect of changes in annual mean temperature by -1 to $3^{\circ} \mathrm{C}$ on (a) tuber potential dry matter yield, (b) the length of the period for which fungicide applications are required, and (c) the potential loss of tuber dry weight caused by late blight. Results of annual simulations over 19611990 at Jokioinen. In 10a and 10b the average effect is shown by the continuous line, 0.05 and 0.95 percentiles by the dotted lines. In 10c the bold lines show the average, 0.05 and 0.95 percentiles of the loss if late blight starts as predicted. The thin lines indicate the respective losses if the onset of epidemic is delayed by 7 days from that predicted.

date of emergence is explained by the temperature model, probably due to its simplicity, as the soil energy balance is not explicitly modelled. However, part of the variation is also caused by delays in planting due to rain and management practices which cannot be taken into account by the model.

The time of epidemic outbreak is largely explained by the daily temperatures in spring, which determine the time of the planting and emergence of potato, and by the number of rainy days in summer and the average temperatures of the rainy days. The outbreak of late blight is pre- 


\section{AGRICULTURAL AND FOOD SCIENCE IN FINLAND}

Kaukoranta, T.: Impact of global warming on potato late blight: risk, yield loss and control

dicted by accumulating 156 DD8 over the days with at least $0.1 \mathrm{~mm}$ of rain after potato emergence. The maximum accumulation of temperature on any one day is 10 degree days. The models for potato emergence and blight outbreak are able to discriminate between early and late outbreaks of late blight, but much of the variation in the dates of outbreak remains unexplained. The long time step of the blight model is one reason for that, as the time coefficients of spore production, germination and infection are shorter than one day (Crosier 1934, Wallin 1953). However, a significant part of the unexplained variation is probably not caused by inadequacies in the models, but by variation in the amount of primary inoculum and weather. The appearance of symptoms and precipitation were sampled at only one point in a region. Values for both symptom appearance and precipitation tend to vary locally, significant differences being found over a distance of 1-5 km. The transformation of precipitation to a discrete scale hides any quantitative effect of the precipitation, but it also prevents occasional local heavy showers from overinfluencing the prediction.

The dependence of the disease on weather is described only for the period preceding the outbreak of the epidemic even though the weather also influences the course of the epidemic after the outbreak. This simplification is justified as slow destruction of the haulm does not necessarily cause less tuber loss than rapid destruction. It is commonly found that the more prolonged the destruction, the higher is the probability of tuber infections and later tuber damage, because the probability of spores being washed down to tubers increases with time (A. O. Hannukkala, pers. comm., Croxall and Smith 1976).

The plot experiments conducted for estimating parameters for the growth model were set up in a large greenhouse. Because of the large space, most of the problems commonly encountered in closed or open-top chambers could be avoided. Chambers often cause variations in temperature, humidity and radiation betweeen plots (Ashenden et al. 1992, Hakala et al. 1996).

The conditions in the plot experiments rep- resented current climatic conditions in southern Finland and those under which the annual mean temperature had risen by $3^{\circ} \mathrm{C}$. Thus the growth model, which predicted the reduction in tuber growth reasonably well, can be used for conditions under which temperatures range from the current to a level at least $3^{\circ} \mathrm{C}$ higher. The yields measured in the experiments are quite low, because the radiation levels in the experiments were lower than under natural conditions and the fertilization and final harvesting dates were suboptimal at elevated temperatures. As the rate of fertilization was the same under both temperature conditions, it was not meaningful to extend growing seasons at elevated temperatures to their maximum possible length.

The values of RUE determined here are a function of the extinction coefficient. This was not determined in the experiments; instead, the value 0.55 reported by Firman and Allen (1989) was used. Slightly lower or much higher values have been reported by Khurana and McLaren (1982), Spitters (1987), Jefferies and Heilbronn (1991) and Haverkort et al. (1991). RUE determined by regression analysis (cf. Fig. 7) ranged from 3.41 to $3.67 \mathrm{~g} / \mathrm{MJ}$. Efficiencies tended to be higher at elevated than at ambient temperatures, but because of experimental error in the dry matter estimates and a potential sampling error in the LAI estimates, it cannot be established that temperature affected RUE. RUE has been reported to vary quite widely due to environmental factors, but the values obtained here are within the range reported by Manrique et al. (1991), Jefferies and McKerron (1989) and Haverkort and Harris (1986).

In this work the only climatic controls considered were precipitation and temperature for late blight epidemics, and radiation and temperature for potato yield accumulation. The increasing concentration of atmospheric carbon dioxide is expected to enhance growth and potential tuber yields (Wheeler et al. 1991, Bowes 1993). This alone would increase the yield losses caused by late blight if relative losses remained at their current level. Adapting to climatic change would require changes in fertilization, which is implic- 


\section{AGRICULTURAL AND FOOD SCIENCE IN FINLAND}

Vol. 5 (1996): 311-327.

itly taken into account in the growth model by assuming that the duration of leaf area could be extended by applying more nutrients over the growing season as temperatures rise. Adjustments in fertilizer use and the increase in the carbon dioxide contrentration could change the carbon/nitrogen ratio in plants, thus possibly affecting the general level of susceptibility of potato to late blight.

The results of the sensitivity study made at one location in southern Finland support the hypothesis that climate warming would considerably increase the impact of late blight. The length of the period during which the disease needs to be controlled by fungicide applications would increase by roughly 10 days per $1^{\circ} \mathrm{C}$ of warming from the current average of 40 days at Jokioinen. The average increase in yield losses due to late blight in unprotected crops would be of the same magnitude as the increase in poten- tial yield, which was estimated to be about $2 \mathrm{t} /$ ha of dry matter per degree of warming. To counter the increased risk, fungicide use would have to be intensified or potato varieties would have to be bred that are significantly more resistant to late blight than they are today.

Acknowledgements. This work is a part of the Finnish Research Programme for Climate Change (SILMU) and was supported, in part, by the Academy of Finland. I acknowledge the Potato Research Insitute, Lammi, Finland for allowing me to use the variety trial data and $\mathrm{H}$. Talvitie, A. Kangas, A. Hannukkala, P. Simojoki, H. Hakkola, J.-P. Palohuhta, H. Kahiluoto, E. Seppänen (Agricultural Research Centre of Finland), A. Rahkonen (Potato Research Institute) and J. Vehmas (Päijät-Häme Agricultural Institute) for supplying the late blight observations. I thank J. Poikulainen and J. Naatula for their help at all stages of the field experiments and A.O. Hannukkala for advice on conducting the field experiments and for providing the inoculum for them.

\section{References}

Ashenden, T.W., Baxter, R. \& Rafarel. C.R. 1992. An inexpensive system for exposing plants in field to elevated concentrations of $\mathrm{CO}_{2}$. Plant, Cell and Environment 15: 365-372.

Beaumont, A. 1947. The dependence on the weather of the dates of outbreak of potato late blight epidemics. Transactions of the British Mycological Society 31: 4553.

Bourke, P. M. A. 1955. The forecasting from weather data of potato blight and other plant diseases and pests. WMO Technical note no. 10.

Bowes, G. 1993. Facing the inevitable: plants and increasing atmospheric $\mathrm{CO}_{2}$. Annual Review of Plant Physiology and Molecular Biology 44: 309-332.

Carter, T. R., Saarikko, R. A. \& Niemi, K. J. 1996. Assessing the risks and uncertainties of regional crop potential under a changing climate in Finland. Agricultural and Food Science in Finland 5: 329-350 (this issue).

Coakley, S. M. 1988. Variation in climate and prediction of disease in plants. Annual Review of Phytopathology 26: 163-181.

Crosier, W. 1934. Studies in the biology of Phytophthora infestans (Mont.) de Bary. Cornell University Memorandum 155.

Croxall, H. E. \& Smith, L. P. 1976. The epidemiology of potato late blight in the East Midlands 1923-74. Annals of Applied Biology 82: 451-466.

Firman, D.M. \& Allen, E.J. 1989. Relationship between light interception, ground cover and leaf area index in potatoes. Journal of Agricultural Science, Cambridge 113: 355-359.

Hakala, K., Kaukoranta, T., Mela, T. \& Laurila, H. 1996. Arrangement of experiments for simulating the effects of elevated temperatures and elevated $\mathrm{CO}_{2}$ on field sown crops in Finland. Agricultural and Food Science in Finland 5: 25-47.

Hansen, J.G, Andersson, B. \& Hermansen, A. 1995. NEGFRY - a system for scheduling chemical control of late blight in potatoes. In: Dowley, L. J. et al. (eds.). Phytophthora infestans 150. E. Boole Press Ltd., Dublin. p. 201-208.

- \& Holm, S. 1991. Validering af Negativ-prognosen til varsling for kartoffelskimmel (Phytophthora infestans). Tidsskrift for Planteavls Specialserie nr. S 2178, 44 p.

Harrington, R. \& Stork, N.E. (eds.). 1995 Insects in a Changing Environment. London, Academic Press. $535 \mathrm{p}$.

Haverkort, A. J.\& Bicamumpaka, M. 1986. Correlation between intercepted radiation and yield of potato crops infested by Phytophthora infestans in Central Africa. Netherlands Journal of Plant Pathology 92: 239-247.

- \& Harris, P.M. 1986. Conversion coefficients between intercepted solar radiation and tuber yields of potato under tropical highland conditions. Potato Research 29: 529-533.

-, Uenk, D., Veroude, H. \& Waart, M. van de 1991. 
Kaukoranta, T.: Impact of global warming on potato late blight: risk, yield loss and control

Relationships between ground cover, intercepted solar radiation, leaf area index and infrared reflectance of potato crops. Potato Research 34: 113-121.

Hirst, J. M. \& Stedman, O. J. 1960. The epidemiology of Phytophthora infestans. II. The source of inoculum. Annals of Applied Biology 48: 489-517.

IImatieteen laitos 1995. Asemaluettelo 30.3.1995, toimivat asemat. IImatieteen laitos, Helsinki.

IPCC 1990. Climate Change: The IPCC Scientific Assesment. Report of Working Group I of the Intergovernmental Panel on Climate Change. (Houghton, J. T. et al. eds.). Cambridge University Press, Gambridge. 200 p.

Jefferies, R.A. \& Heilbronn, T.D. 1991. Water stress as a constraint on growth in the potato crop. 1. Model development. Agricultural and Forest Meteorology 53: 185196.

- \& McKerron, D.K.L. 1989. Radiation interception and growth of irrigated and droughted potato (Solanum tuberosum). Field Crops Research 22: 101-112.

Khurana, S.C. \& McLaren, J.S. 1982. The influence of leaf area, light interception and season on potato growth and yield. Potato Research 25: 329-342.

Krause, R. A., Massie, L. B. \& Hyre, R. A. 1975. Blitecast, a computerized forecast of potato late blight. Plant Disease Reporter 59: 95-98.

Maatalouden tutkimuskeskus 1988. ATK-tiedote nro. 59. MTT, Jokioinen. 23 p.

MacKerron, D.K.L. \& Waister, P.D. 1985. A simple model of potato growth and yield. 1. Model development and sensitivity analysis. Agricultural and Forest Meteorology 34: 241-252.

Manrique, L.A., Kiriny, J.R., Hodges, T. \& Axness, D.S. 1991. Dry matter production and radiation interception of potato. Crop Science 31: 1044-1049.

Monteith, J.L. \& Unsworth, M.H. 1990. Principles of
Environmental Physics. 2nd ed. Edward Arnold, London. $291 \mathrm{p}$.

Oijen, M. van. 1991. Light use efficiencies of potato cultivars with late blight (Phytophthora infestans). Potato Research 34: 123-132.

Perunakoetuloksia 1977, 1979, 1980. Hämeen Peruna Oy. Hämeenlinna.

Perunantutkimuslaitoksen koetuloksia 1983-1994 (annually). Perunantutkimuslaitos. Lammi.

Rotem, J., Bashi, E. \& Kranz, J. 1983. Studies of crop loss in potato blight caused by Phytophthora infestans. Plant Pathology 32: 117-122.

Smith, L. P. \& Seager, J. M. 1974. Comparison of Beaumont and 90 per cent relative humidity criteria in relation to potato blight outbreaks. Agricultural Memorandum no. 672: 1-13.

Spitters, C.J.T. 1987. An analysis of variation in yield among potato cultivars in terms of light absorption, light utilization and dry matter partitioning. Acta Horticulturae 214: 71-84

Ulirich, J. \& Schrödter, H. 1965. Das Problem der Vorhersage des Auftretens der Kartoffelkrautfäule (Phytophthora infestans) und die Möglichkeit seiner Lösung durch eine "Negativprognose". Nachrichtenblatt des Deutchen Pflanzenschutzdienstes 18: 33-40.

Wallin, J. R. 1953. The production and survival of sporangia of Phytophthora infestans on tomato and potato plants in the field. Phytopathology 43: 505-508.

- 1962. Summary of recent progress in predicting late blight epidemics in the United States and Canada. American Potato Journal 39: 306-312.

Wheeler, R. M., Tibbits, T. W. \& Fitzpatrick, A. H. 1991. Carbon dioxide effects on potato growth under different photoperiods and irradiance. Crop Science 31: 12091213. 
Vol. 5 (1996): 311-327.

\title{
SELOSTUS
}

\section{Ilmaston lämpenemisen vaikutus perunaruttoon}

\author{
Timo Kaukoranta \\ Maatalouden tutkimuskeskus
}

\begin{abstract}
Ilmaston lämpenemisen vaikutusta perunaruton aiheuttamaan satotappioon ja ruton torjuntatarpeeseen tutkittiin rakentamalla malli ruttoepidemian ajoittamiseen ja malli perunan kasvusta ruton rajoittamana. Perunan istutus- ja taimettumisaika ennustetaan tehoisan lämpösumman kertymisellä ja ruttoepidemian alkamisaika tehoisan lämpösumman kertymisellä sadepäivinä. Kasvumallin parametrit arvioitiin perunan kasvun mittauksista, jotka tehtiin normaalissa ja kohotetussa $\left(+3{ }^{\circ} \mathrm{C}\right)$ lämpötilassa $1993-1995$. Perunan ennustetaan taimettuvan, kun yli $0{ }^{\circ} \mathrm{C}$ laskettu lämpösumma saavuttaa 631 astepäivää. Lämpösumman laskeminen aloitetaan keväällä 16 vrk:n keskilämpötilan noustessa yli $0{ }^{\circ} \mathrm{C}$. Ruttoepidemian ennus-
\end{abstract}

tetaan alkavan, kun taimettumisesta alkaen laskettu sadepäivien (sade $\geq 0,1 \mathrm{~mm}$ ) lämpösumma saavuttaa 156 astepäivää. Lämpösumman päivittäinen kertymä ruton ennustamisessa on korkeintaan $10^{\circ} \mathrm{C}$. Jokioisten säähavaintoja käyttäen tehtiin alustava herkkyyskoe $1-3^{\circ} \mathrm{C}$ suuruisen lämpötilan nousun vaikutuksesta ruttoon ja perunan kasvuun. Aika, jolloin peruna täytyy suojata rutolta fungisidiruiskutuksella, pitenee $10-20$ päivää $1^{\circ} \mathrm{C}$ lämpenemistä kohti. Ilmaston lämpenemisen aiheuttama satotappioitten kasvu rutolta suojaamattomissa kasvustoissa on samaa suuruusluokkaa kuin satopotentiaalin kasvu: noin $2 \mathrm{t} / \mathrm{ha}$ kuiva-ainetta $1{ }^{\circ} \mathrm{C}$ lämpenemistä kohti. 